\title{
PENGEMBANGAN SISTEM KENDALI SPEKTROMETER SMALL ANGLE NEUTRON SCATTERING (SANS) BERBASIS JARINGAN
}

\author{
Sukarman, C. Yunida Mitra Cahyani, Bharoto \\ Jurusan Teknofisika Nuklir, \\ Sekolah Tinggi Teknologi Nuklir - Badan Tenaga Nuklir Nasional \\ Jl. Babarsari PO BOX 6101/YKBB Yogyakarta 55281 \\ Telp : $(0274) 48085 ;$ Fax : $(0274) 489715$ \\ Homepage:www.stin-batan.ac.id

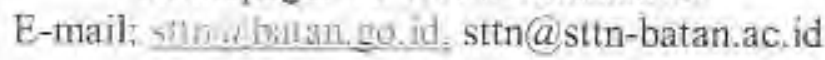

\begin{abstract}
ABSTRAK
PENGEMBANGAN SISTEM KENDALI SPEKTROMETER SMALLANGLE NEUTRON SCATTERING (SANS) BERBASIS JARINGAN. Optimalisasi sistem kendali spektrometet SANS sangat diperlukan mengingat penggunaan SANS yung begitu luas. Salah sătunya dengan menggunakan jaringar puda sistem kendali, karena memudahkan upgrade komputer dan dapat dikendalikannya spektrometer SANS pada jarak jauk, mika pada penclitian ini dikembangkan sisiem kendali spektrometer small angle neutron scaulering (SANS) berbasis jaringan. Sistem ini menyirunakun terminal konektor yang menghubungkan motion cotroller PMX-4ET-SA-TBS dengan motor driver Vexta 5 phasa yaitu dengan motion controller yang dihubusgkan dengan jaringan ethelnet. Sistem ini dilengkapi dengan sensor magnetic switch scbagai pengaman pergerakan motor stepper dar juga software visual basic 6.0 untuk menggerakkan motor stepper. Mejalui hasil pengujiàn, motor stepper bergerak menuju posisi yang dïnginkan, schingga pengembangan sistem kendali spektrometer small angle neutron scattering (SANS) telah berfingsi dengan baik,
\end{abstract}

Kata Kunci : Sistem Kendali, small angle neutron scattering (SANS), PMX-4ET-SA-TBS

\section{ABSTRACT}

CONTROL SYSTEM DEVELOPMENT OF SMALL ANGLE NEUTRON SCATTERING (SANS) SPECTROMETER BASED ON NETWORK, Optiwization of connol system spectrometer SAINS is fiery needed considering the nse of SANS extendly. One of them is by using a nerwork for contor systemis. hecause it allaws the computer upgrades and SANS spectrometer can be controlled at a distance, so in this study the confrol systum developed small angle neutron seattering speciromeler (SASS) based on network. This system uses a terminat connector that contects motion controller PMX-4ET-S4-TBS with a Texto 5phase motor driver. The system is equipped with a magnetic switch sensor and also sofiware program with wisual hasic 6 to drive the motor. Through the calibration resthls siepper motors move towards the desired position, so that the control sistem detelopmen of small angle neturon scattering (SANS) spectrameter has been functioning nell.

Keyisonits Control System, shail angle neutron scattering (SANS). PMLX-dET-SA-TBS

\section{PENDAHULUAN \\ Latar Belakang}

Spektrometer Neutron Hamburan Sudul Kecil (Small Angle Neutron Scatering Spectrometer, SiNS) adalah sebuah peralatan yang berfingsi untuk mengamati pola hamburan pada sudut kecil sehingga memberikan gambaran tentang obyek atau dimensi berukuran 1-100 $\mathrm{mm}$ pada berbagai jenis bahan seperti logam. polimer, keramik, koloid, protein, dan lainnya dalam bentuk padatan, sebuk. lapisan tipis hingga larutan: SANS (SMARTer) di konstruksi pada tahun 1992 dengan computer utama IBM PS2/70 yang beroperasi dengan sistem $\mathrm{AIX}$ (Advanced Interactive Execuifive) untuk sistem 
kendali dan akuisisi data. SANS (SMARTer) ini merupakan SANS spectrometer terbesar kedua yang beroperasi di wilayah Asia-Pasifik sat ini, tetapi spectrometer tersebut tidak dimanfaatkan dengan baik sampai tahun 2004 karena kekurangan anggota staf, kegagalan imstrumen dan program penelitian jangka panjang yang tidak terdefinisi. SANS mulai digunakan kembali pada tahum 2005 dengan perubahan sistem operasi AIX digantikan dengan menggunakan koneksi antarmuka ISA (Industry Standard Architecture) pada sistem kendalinya dan GPIB (General Purpose Interface Bus) untuk mengumpulkan data yang akan diakuisisi dari detektor 2-dimensi pada computer yang terpisah. Karena perkembangan zaman dan teknologi maka sistem kendali SANS mengalami perubahan kembali yaitu penggantian koneksi antarmuka ISA card dengan PCI (Peripheral Component Interconnect) card. $\mathrm{PCl}$ card ini dapat mengendálikan pergerakan semua motor, antara lain kolimator, pinhole, dan detektor secara bersamaan. Dalam penggunaannya $\mathrm{PCl}$ card mempunyai kelemshan sebagai motion controller yaitu susahnya upgrade computer apabila terjadi kerusakan sehingga membutuhkan waktu yang lama untuk memperbaiki kerusakan tersebut dan $\mathrm{PCl}$ Card tidak dapat dihubungkan dengan jaringan sehingga tidak dapat dilakukan monitoring pada jarak jauh. Oleh sebab ira untuk mengoptimalisasi kerja sistem kendali SANS, maka pada penelitian ini dikembangkan sistem kendali spektrometer small angle neutron scattering (SANS) berbasis jaringan dengan menggunakan PMX4E, T-SA-TBS sébagai motion controller yang. dilubungkan menggunakan jaringan LAN Aocul Area Nerwork').

\section{Dasar Teori}

\section{Sistem Kendali}

Sistem kendali adalah hubungan antara komponen-komponen fisik yang membentuk suatu konfigurasi sistem sehinggmemberikan hasil yang diharapkan. Sistem kendali ada 2 jenis yaitu:

1. Sistem kendali Untaian Terbuka (open loop)

Sistem kendali untaian terbuka adalah sebuah sistem yang tidak memiliki umpan balik (feedback), sehingga bila terdapat gangguan dari dalam maupun dati luar maka sistem tidak dapat melaksanakan rugas seperti yang diharapkan. Proses untaian terbuka dapat dilihat pada Gambar I.

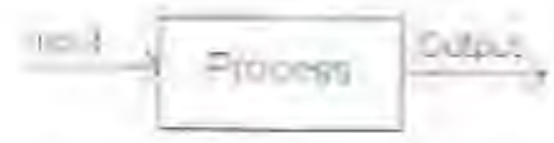

Gambar 1. Proses Untaian Terbuka (Open Loop)

2. Sistem Kendali Untaian Tertutup (closed loop)

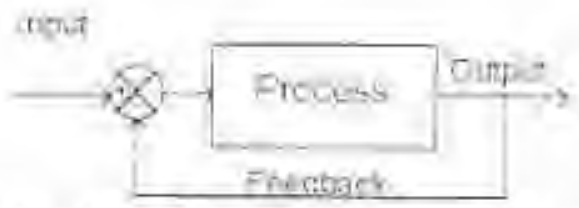

Gambar 2. Proses Kerja Sistem Untaian Tertutup (Closed Loop)

\section{Tcknik Hamburan Neutron Sudut Kecil}

Teknik hamburan neutron sudut kecil atau Small Angle Neutron Scattering (SANS) merupakan tekmik yang utama untuk investigasi struktur yang meliputi ukuran. bentuk, orientasi, konformasi dan sifat dinamik makromolekul suatu material dan bahan-bahan biologi pada rentang ukuran (1100) nm, dalam memahami mekanisme molecular self-assembly dan interaksinya. ${ }^{[2]}$

Spcktrometer ini terdiri dari sistem kolimator tabung sepanjang $18 \mathrm{~m}$ yang memiliki empat bagian tabung utama yang dapat dipindahkan serta satu bagian kolimaior yang tetap. Detektor pada spektrometer SANS dapat dipindahkan secara kontinu dari (1,3-18) m dari posisi sampel dan juga dapat bergeser dalam arah lateral sebesar $0,1 \mathrm{~m}$ untuk meningkatkan jangkauan Q (Quasi). Variasi panjang kolimator dan jarak sampel hingga detektor (PSD) sepentuhnya dikendalikan oleh kormputer [2]. Gambar 3. adalah gambar skematik dări alat SANS. 


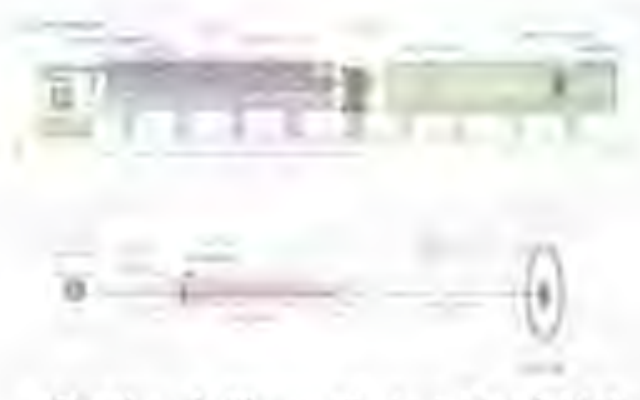

Gambar 3. Skematik dari Alat SANS

\section{Kolimator}

Tabung spektrometer SANS terdiri dari 2 jenis tabung yaitu Neutron Guide Tube dan Non Reflecting. Guide Tube yang masing masing memiliki diameter sebesar $150 \mathrm{~mm}^{2}$. Pada sistem kolimasi spektrometer SANS ini tabung kolimator terdiri dari empat bagian kolimator yang dapat digerakkan yaitu:

- Kolimator 1 dengan panjang $5 \mathrm{~m}$

- Kolimator 2 dengan panjang $5 \mathrm{~m}$

- Kolimator 3 dengan panjang $4 \mathrm{~m}$

- Kolimator 4 dengan panjang $2.5 \mathrm{~m}$

Gambar 4, menunjukkan kolimator yang ada di spektrometer SANS:

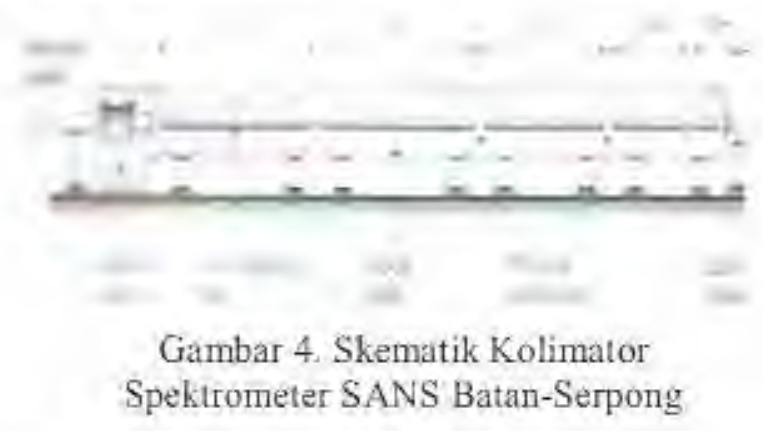

\section{Pinhole}

Piringan pinhole diletakkan dalam tabung kolimator diantara dua bagian dari tabung, pada jarak $18,13,8,4,1,5$, dan $1 \mathrm{~m}$ dari posisi sampel dengan ukuran pinhole ditunjukkan pada Gambar 5. sebagai berikut:

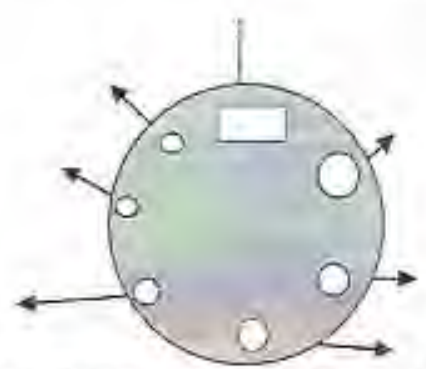

Gambar 5. Penampakan Melintang Pinhole Detektor
Detektor digunakan untuk mendeteksi dan mengumpulkan berkas hamburan dari sampel. Detektor yang digunakan pada spektrometer SANS adalah 2D-PSD (2Dimensional Positive Sensitive Detector) He $128 \times 128$ channel dengan ukuran fisik $64 \times$ $64 \mathrm{~cm}$ buatan Ris $\emptyset$ dan detektor ini memiliki resolusi $5 \mathrm{~mm}$. Gambar 6 menunjukkan detektor pada spectrometer SANS sebagai berikut:

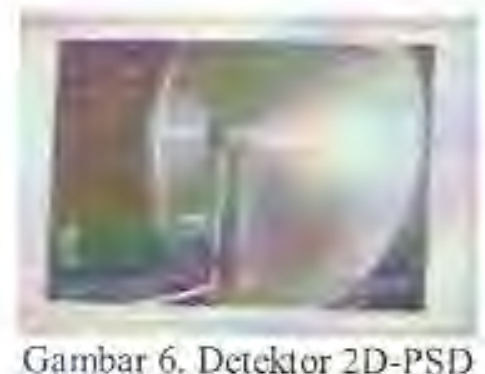

Detektor ini dapat digerakkan dari jarak 1.3 $18 \mathrm{~m}$ dari posisi sampel. ${ }^{\text {(3) }}$

\section{Ethernet}

LAN memiliki banyak protokol, salah satunya adalab protokol Ethernet. Protokol Ethernet merupakan protokol LAN yang paling banyak dipakai karena berkemapuan tinggi dengan biaya yang rendah. Kecepatan yang bisa dicapai adalah dari $10 \mathrm{Mbps}$. Cara kerja dari Protokol Ethernet yakni sebelum mengirim data, suatu komputer memeriksa apakah netuork (jaringan) terdapat pengiriman data, Jika tidak ada pengiriman data (network sepi), komputer tersebut akan melakukan pengiriman data. Jika network sibuk, komputer akan menunggu sampai network sepi. Bila 2 komputer pada saat yang bersamaan melakukan pengiriman data. terjadilah tabrakan (collision). Jika hal ini terjadi, kedua komputer mengirimkan sinyal jam ke network dan semua komputer berhenti mengirimkan data dan kembali menunggu. Kemudian secura random. semua komputer menunggu dan mengirimkan data kembali Backoff algorithm digunakan untuk mengatur pengiriman ulang setelah terjadi tabrakan. ${ }^{\text {i }}$

\section{Motor Stepper}

Motor stepper adalah perangkat elektromekanis yang bekerja dengan mengubah pulsa elektronis menjadi gerakan mekanis diskrit. Motor stepper bergerak 
berdasarkan urutan pulsa yang diberikan kepada motor ${ }^{[4]}$ Penggunaan motor stepper mempunyai keunggulan dibandingkan dengan penggunaan motor DC biasa.

Keunggulannya antara lain adalah:

- Sudut rotasi motor proporsional dengan pulsa masukan sehingga mudah diatur.

- Motor dapat langsung memberikan torsi penuh pada saat mulai bergerak.

- Posisi dan pergerakan repetísinya dapat ditentukan secara presisi.

- Memiliki respon yang sangat baik terhadap mulai, stop dan berbalik (perputaran).

- Frekuensi perputaran dapat ditentukan secara bebas dan mudah pada range yang luas. ${ }^{|5|}$

\section{Visual basic}

Visual Basio merupakan bahasa pemrograman yang sangat mudah dipelajari, dengan teknik pemrogtaman visual yang memungkinkan penggunanya berkreasi lebih baik dalam menghasilkan suatu program aplikasi. Penggunaan visual basic sangatlah sesuai karena visual basic sendiri adalah program dengan bahasa yang sederhana dan mempunyai aplikasi pada tools yang bermacam-macam ${ }^{[6]}$

\section{METODE}

Diagram Blok Pembuatan Perangkat Keras Perancangan dan pembuatan perangkat keras mengikuti blok diagram yang ditunjukkan pada Gambar 7.

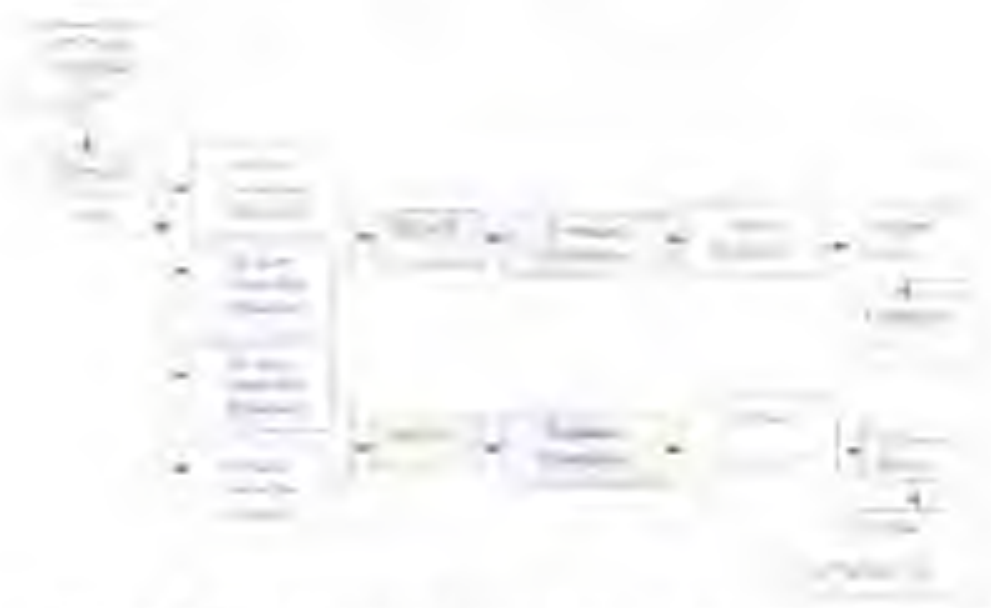

Gambar 7. Blok Diagram SistemKendali Spekirometer SANS

Prinsip kerja dari sistem tersebut adalah personal computer bertindak sebagai executor sistem kendali yang telah diprogram dengan menggunakan softwate visual basic yang diimplementasikan pada motion controller PMX-4ET-SA-TBS. Personal computer ini dihubungkan dengan motion controller PMX-4ET-SA- TBS dengan menggunakan jaringan ethernet. Keluaran motion coniroller (dir,pulse) digunakan sebagai masukan relay untuk menentukan arah putaran motor stepper, kemudian keluaran relay dihubungkan ke terminal konektor, dengan terminal konektor menupakan rangkaian penghubung atau pemberi masukan pada motor driver sehingga motor stepper dapat menggerakkan kolimator, pinhole, detektor.

\section{Pembuatan Perangkat Keras Rangkaian Relay}

Gambar 8. menunjukkan rangkaian relay

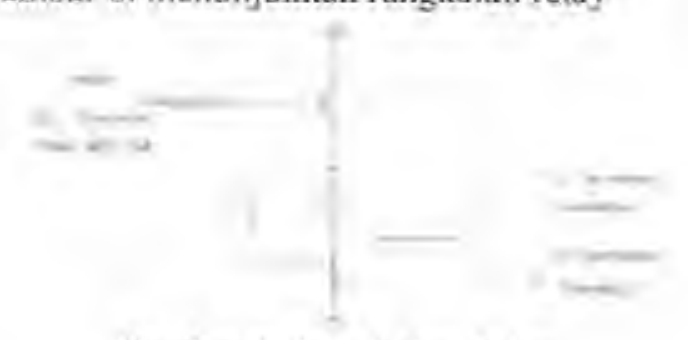

Gambar 8. Rangkaian Relay

Rangkaian relay digunakan untuk menghubungkan keluaran motion controller PMX-4ET-SA-TBS yang berupa keluaran digital (1 atau 0) dengan terminal konektor untuk menggerakkan motor slepper ke arah CW (Counter Wise) yaitu searah jarum jam ataupun CCW (Conmter Clock Wise) yaitu 
berlawanan arah jarum jam

\section{Terminal Konektor}

Terminal konektor digunakan untuk menghubungkan motion controller PMX-4ETSA-TBS dengan motor driver vexta 5 phasa. Terminal konektor ini menghubungkan dari relay dan PMX-4ET-SA-TBS ke motor driver ((kolimator, pinhole, detektor). LS (kolimator, pinhole, detektor), serta datum (untuk pinhole). Terminal ini juga mengatur adanya limit untuk membatasi pulsa maksimal dan minimal pergerakan suatu motor dan juga LED sebagai indikator.

1) Terminal Konektor Kolimator

Terminal Konektor ditunjukkan pada Gambar 9.

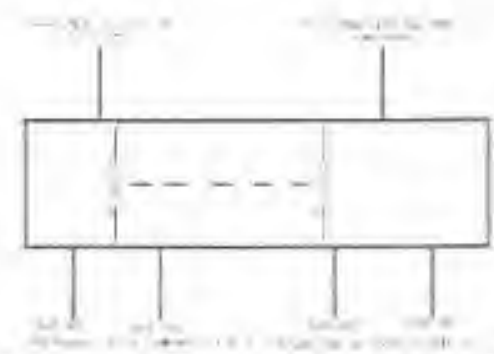

Gambar 9. Terminal Konektor Kolimator

2) Terminal Konektor Detektor

Gambar I0. menunjukkan terminal konektor detektor.

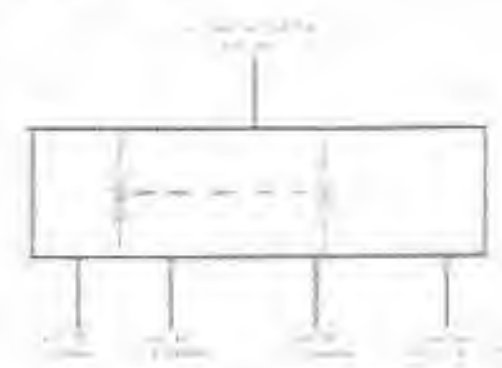

Gambar 10. Terminal Konektor Detektor

3) Terminal Konektor Pinhole

Gambar 11 menunjukkan terminal konektor pinhole.

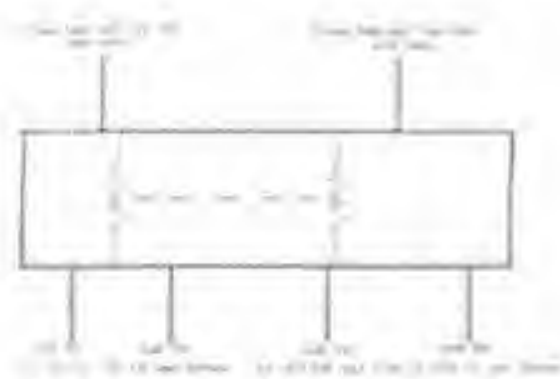

Gambar 11. Terminal Konektor Pinhole

Pembuatan Perangkat Lunak

Pembuatan perangkat berdasarkan perancangan alur proses kerja program yang ditunjukkan pada Gambar 12 sebagai berikut 
Tabel 1. Hasil Pengujian Relay

\begin{tabular}{|c|c|c|c|}
\hline Bune: & Treme te CISAl & Ramass Bou & set \\
\hline$y^{3}+1$ & & & 71 \\
\hline
\end{tabular}

Dari data Tabel 1 didapat tegangan otstpu! relay sebesar 5 volt saat kondisi relay. terhubung dan kontak normally open aktif sedangkan normally close tidak aktif , dan sebaliknya.

\section{Hasil Pengujian Sensor Magnetic Switch}

Pengujian sensor magnetic switch dilakukan dengan cara mendekatkan dan menjauhkan logam pada sensor magnetic Pengujian dilakukan dengan menghidupkan motor stepper pada kolimator, kemudian mendekatkan logam pada sensor magnetic switch, apabila sensor magnet mendeteksi logam maka secara otomatis motor akan berhenti karena sensor magnetic disini digunakan sebagai kolimator agar kolimator tidak bergerak diluar jangkauan. Saat sensor tidak mendeteksi magnet maka motor tetap bergerak dan mengeluarkan keluaran seperti yang ditunjukkan pada Tabel 2 sebagai berikut:

Tabel 2. Hasil Pengujian Sensor Magnetic Switch

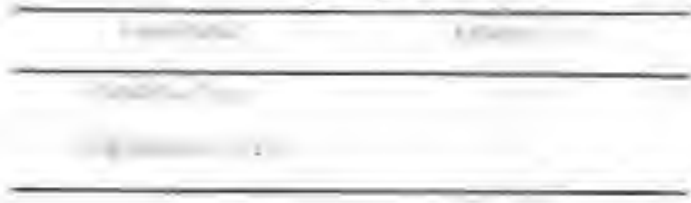

Dari hasil pengujian seperti yang ditunjukkan Tabel 2 keluaran sensot pada saat sensor mendeteksi magnet adalah 18,16 volt dan berlogika high, sedangkan saat sensor tidak mendeteksi magnet, keluaran sensor sebesar 3 volt dan berlogika low.

\section{Hasil Pengujian Motor Stepper Penggerak Pintole}

Pada pinhole dilakukan pengujian pergerakan motor stepper untuk themutar pinhole pada lubang (mm) yang diinginkan dengan jumlah pulsa untuk masing-másing lubang (mm) pin/role. Percobaan dilakukan dengan tujuan untuk mengetahui pulsa yang tepat untuk masing-masing lubang (mm) pada pinhole, Tabel 3 menunjukkan hasil percobaan pengujian motor stepper pada pinhole:

Tabel 3 Hasil Pengujian Pergerakan Motor Stepper Pinhole

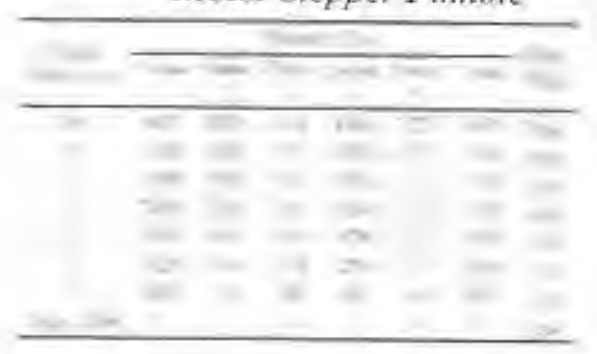

Dari hasil percobaan dihasilkan pergerakan motor stepper sudah presist atau sudah tepat sesuai dengan ukuran pinhole dan jumlah pulsa yang di butulikan untuk masing- masing ukuran lubang pinhole.

\section{Hasil Pengujian Motor Stepper Penggerak Detektor}

Pengujian detektor dilikukan unfuk mengetahui jumlah pulsa yang dibutuhkan untuk menggerakkan detektor pada tap meternya. Serupa dengan pinhole, detektor juga merniliki pulsa acuan pada penelitian sebelumnya yaitu 16 pulsa untuk tiap milimeternya (mm), sehingga dibutuhkan pulsa sebanyak 16000 pulsa untuk tiap meternya (m). Detektor digerakkan dengan jangkauan jarak antara $1300 \mathrm{~mm}$ sampai 18000 mm.Tabel 4 mentunjukkan hasil pengujian gerakan motor stepper pada detektor.

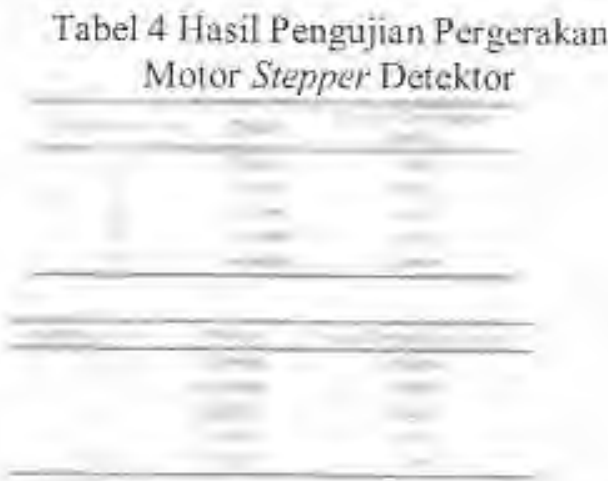

Dari Tabel 4 dapat dilihat bahwa jumlah pulsa yang dibutuhkan motor stepper untuk menggerakkan detcktor sesuai/sami dengan pulsa acuan yaitu 16000 pulsa untuk tiap meternya, untuk menggerakkan detektor ke jarak J,3 m dibutuhkan 20800 pulsa, jarak 2 m dibutuhkan 32000 pulsa, jarak 4 m dibutuhkan 64000 pulsa, jarak $7 \mathrm{~m}$ dibutuhkan 
112000 pulsă, dan jàrak $10 \mathrm{~m}$ dibutuhkan 160000 pulsa. Dari hasil pengujian yang dilakukan didapatkan pergerakan motor stepper untuk detektor sudah presisi atau sudah tepat sesuai dengan jarak detektor yang ditinginkan.

\section{Pengujian Motor Stepper Penggerak Kolimator}

Pengujian kolimator dilakukan untuk mengetahui jumlah pulsa yang tepat untuk menggerakkan kolimator pada posisi Guide Tube ataupun NR Tube. Dalam hat ini posisi Guide Tube merupakan, posisi kolimator pada saat kolimator berada pada posisi di atas, dan posisi NR Tube merupakan posisi kolimator saat kolimator berada di bawah. Dengan menggunakan pulsa seperti pada penelitian sebelumnya yaitu untuk posisi Guide Tube sebesar 80000 pulsa dan posisi NR Tube sebesar 20000 pulsa didapatkan hasil pengujian seperti ditunjukkan pada Tabel 5

Tabel 5 Hasil Pengujian Pergerakan Motor Stepper Kolimator

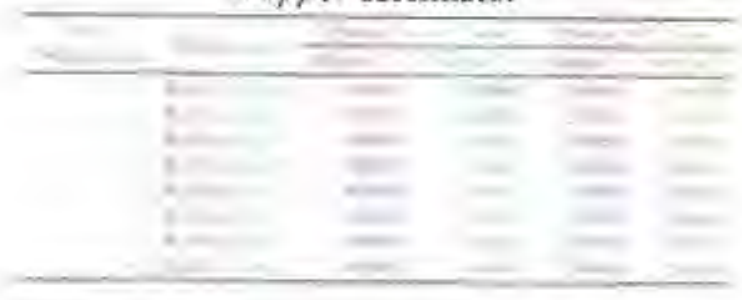

Dari hasil pengujian didapatkan pulsayang dibutuhkan motor stepper untuk menggerakkan kolimator 1 , kolimator 2 , kolimator 3, dan kolimator 4 ke posisi Guide Tube sama dengan penelitian sebelumnya yaitu sebanyak 80000 pulsa. Banyak pulsa yang dibutuhkan motor stcpper untuk menggerakkan kolimator 1 , kolimator 2, kolimator 3, kolimator 4 ke posisi NR Tube sebanyak 20000 pulsa. Pada Pengujian ini motor bergerak sesuai dengan tujuan (Guide Tuhe, NR Tube) yang diinginkan. Motor 1 dan motor 2 bergerak secara bersamaan dan tidak ada selisih antara motor I dan motor 2 sehingga kolimator berada pada posisi yang tepat dan presisi.

\section{Hasil Pengujian Penggunaan Jaringan LAN (Ethernet)}

Pengujian penggunaan jaringan ethernet dilakukan dengan menghubungkan ke 4 motion controller PMX-4ET-SA-TBS dan personal computer ke ethernet switch tub. Pada saat program dijalankan maka akan muncul tampilanl login seperti pada gambar 13 sebagai berikut :

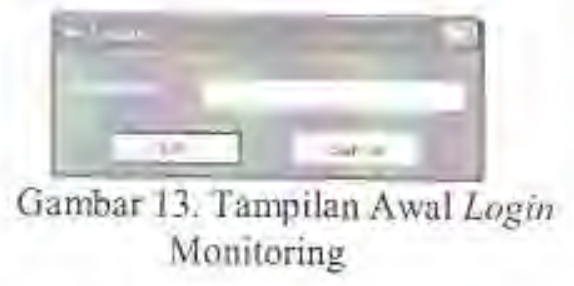

Pada tampilan login apabila passuord yang dimasukkan berisi "monitoring" maka akan muncul tampilan monitoring seperti pada Gambar I4 sebagai berikut:

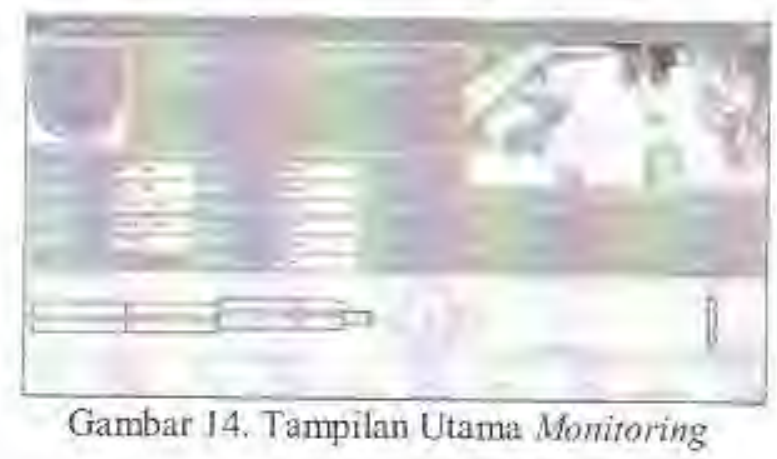

Dari hasil pengujian, dapat dilihat bahwa jaringan ethernet dapat digunakan, hal ini terlihat dari awal saat password dimasukkan, jika password dapat dimasukkan dan muneuI tampilan monitoring maka dapat dikatakan bahwa jaringan ethernet dapat dihubungkan dengan baik.

\section{Hasil Pengujian Perangkat Lunak (Software)}

Secara otomatis, pada saat pertama kali menjalankan program visual basic untuk program sistem kendali SANS akan tampil kotak dialog Login seperti yang terlihat pada ilustrasi Gambar 15.

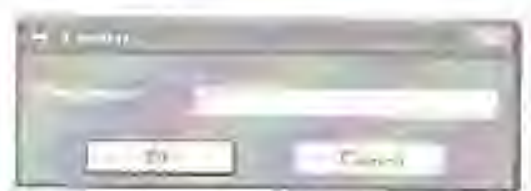

Gambar 15. Tampilam Awal Login Kendali

Apabila pada kotak passuord disi dengan "kendali" maka akan tertampil tampilan utama dilengkapi dengan tombol pilihan alat yang akan digerakkan seperti yang ditunjukkan 
pada gambar 16 sebagai berikut:

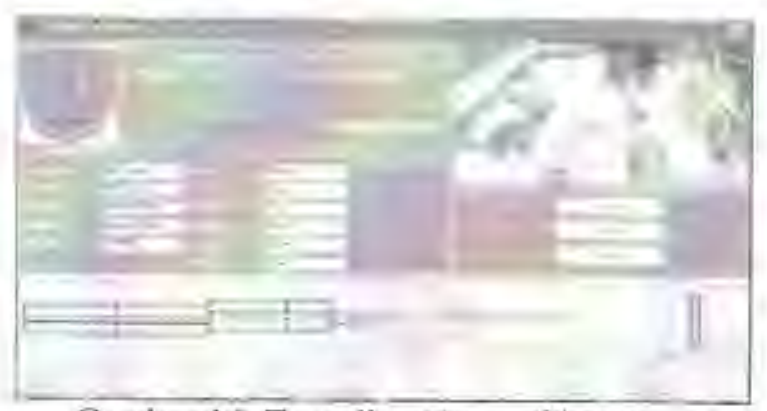

Gambar 16. Tampilan Utama Sistem Kendali SANS

Pada tampilan utama sistem kendali SANS terdapat frame Equipment Status yang berisi display posisi masing- masing alat, Pada tampilan utama juga terdapat gambar simulasi untuk masing- masing kolimator dan detektor, ketika kolimator atau detektor dijalankan, gambar akan bergerak mengikuti pergerakan alat yang digerakkan dan gambar akan berhenti apabila alat sudah mencapaj titik yang diinginkan. Pada tampilat utams juga terdapat 3 tombol command yaitu tombol Collimator, Detector, dan Pinhole, Tombol ini apabila ditekan akan muncul tampilan pengendai untuk masing-masing alat. Apabila tombol Collimotor ditekan, maka akan muncul tampilan kendali kolimator seperti pada Gambar 17.

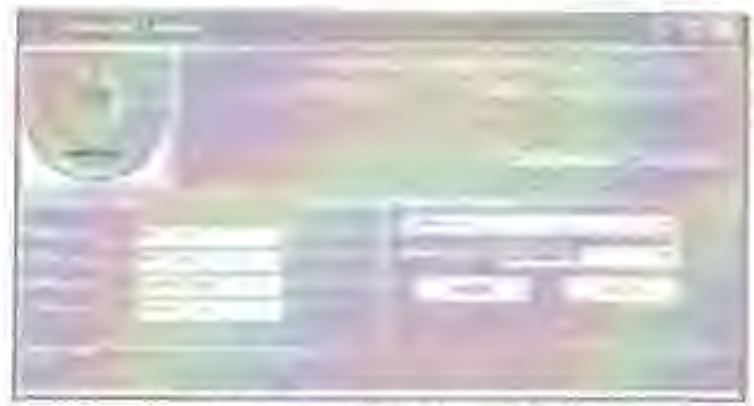

Gambar 17. Tampilan Kendali Kolimator

Pada tampilan kendali kolimator terdapat frame Position Status, frame int berisi display posisi untuk másing-masing kolimator, display ini akan berisi posisi terakhir masing-masing kolimator sebelum kolimator digerakkan dan display akan berisi posisi kolimator setelah kolimator digerakkan. Pada tampilan kendali kolimator terdapat frame Devices Control yang berisi 2 combo pilihan, yaitu combo I berisi pilihan kolimator yang akan digerakkan dan combo pilihan Change To berisi pilihan kemana kolimator akan digerakkan yaitu posisi Gride Tube dan NR Tube. Tombol MOVE merupakan tombol untuk menggerakkan kolimator sesuai dengan posisi yang telah di atur pada combo Change to sedangkan tombol STOP digunakan untuk menghentikan gerakan kolimator secara bersamaan. Apabila tombol MOVE ditekan maka kolimator akan bergerak sesuai dengan posisi yang dipilih pada combo Change To, dan setelah kolimator berada pada posisi yang dituju maka posisi terakhir setelah kolimator digerakkan akan disimpan dalam bentuk logfile ditunjukkan pada Gambar I8.

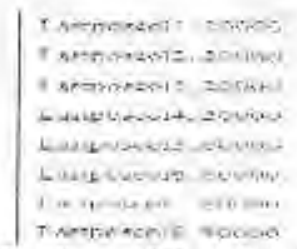

Gambar 18 Logfile Kolimator

Dari logfile di atas disimpan posisi terakhir kolimator, ketika Lastposcoll, 20000 diartikan bahwa motor 1 pada kolimator 1 berada pada posisi NR Tube, 20000. Dalam hal ini pulsa yang dibutuhkan oleh kolimator untuk bergerak ke posisi NR Tube sedangkan 80000 merupakan pulsa yang dibutuhkan kolimator untuk bergerak ke posisi Guide Tube. Lastposcol2, 20000 diartikan bahwa motor 2 kolimator 1 betada pada posisi $N R$ Tube. Lastposcol3, 20000 diartikan bahwa motor 3 pada kolimator 2 berada pada posisi NR Tube. Lastposcol4, 20000 diartikan bahwa motor 4 pada kolimator 2 berada pada posisi NR Tube Lastposcol5, 80000 berarti motor 5 pada kolimator 3 berada pada posisi Guide Tube Lastposcol6, 80000 berarti motor 6 pada kolimator 3 berada pada posisi Guide Tube Lastposcol7. 80000 berarti motor 7 pada kolimator 4 berada pada posisi Guide Tube Lastposcols, 80000 berarti motor 8 pada kolimator 4 berada pada posisi Guide Tube. Apabila pada tampilan utama sistem kendali SANS tombol Pinhole ditekan maka akan muncul tampilan kendali untuk menggerakkan pinhole seperti pada Gambar 19. 


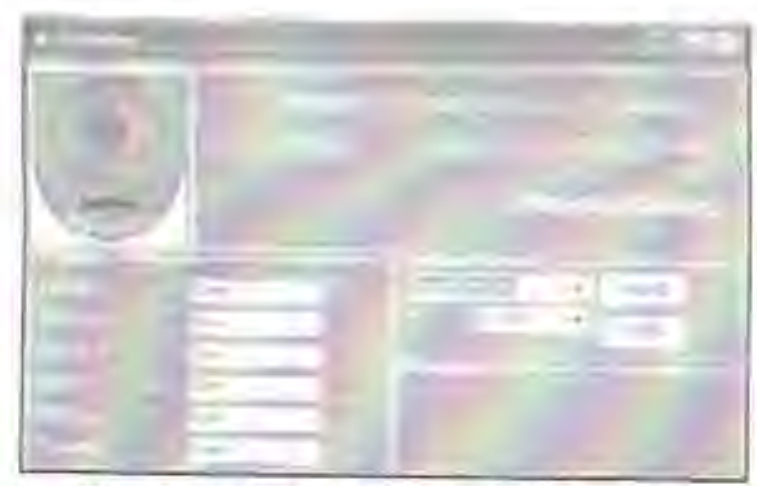

Gambar 19, Tampilan Kendali Pinhole

Pada tampilan kendali pinhole terdapat frame Position Status yang berisi display posisi masing-masing Pinhole yaitu posisi Pinhole untuk lubang open, $30 \mathrm{~mm}, 20 \mathrm{~mm}, 14 \mathrm{~mm}$, $10 \mathrm{~mm}, 7 \mathrm{~mm}, 5 \mathrm{~mm}$, dan posisi close. Posisi yang tertampil pada display merupakan posisi terakhir pinhole sebelum pinhole digerakkan dan posisi terakhir setelah pinhole digerakkan. Pada tampilan kendali pinhole ini terdapat Form Devices Control yang berisi kotak pilihan pinhole yang akan digerakkan dan kotak Position untuk memilih ukuran lubang yang di inginkan yaitu pilikan Open, $30 \mathrm{~mm}, 20 \mathrm{~mm}, 14 \mathrm{~mm}, 10 \mathrm{~mm}$, $7 \mathrm{~mm}, 5 \mathrm{~mm}$, dan Close. Setelah Pinhole dan ukuran lubang Pinhole sudah ditentukan maka untuk menggerakkannya digunakan tombol MOVE, apabila tombol MOVE ditekan maka motor akan bergerak ke posisi yang diinginkan. Dan setelah Motor berhenti maka posisi terakhir pinhole setelah digerakkan akan disimpan dalam bentuk logfile seperti yang ditunjukkan pada Gambar 20.

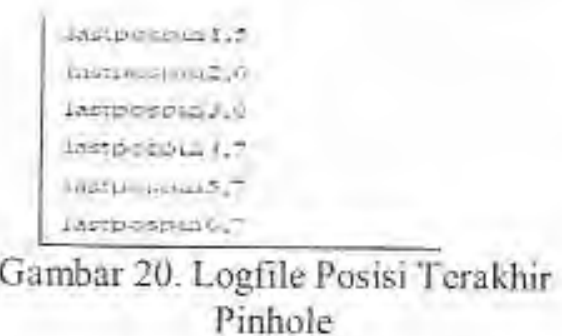

Pada logfile ini angka setelah koma (.) menunjukkan lubang pinhole, dengan 0 berarti lubang close, 1 berarti lubang $5 \mathrm{~mm}_{7} 2$ berarti lubang $7 \mathrm{~mm}, 3$ berarti lubang 10 $\mathrm{mm}, 4$ berarti lubang $14 \mathrm{~mm}$, 5 berarti lubang
$20 \mathrm{~mm}$. 6 berarti lubang $30 \mathrm{~mm}$, dan 7 berarti lubang open. Tombol STOP pada tampilan kendali pinhole berfungsi untuk menghentikan motor secara bersamatun. Dan jika tombol Detektor pada tampilan utama sistem kendali SANS ditekan maka akan muncul tampilan kendali Detektor seperti Gambar 21, sebagai berikut:

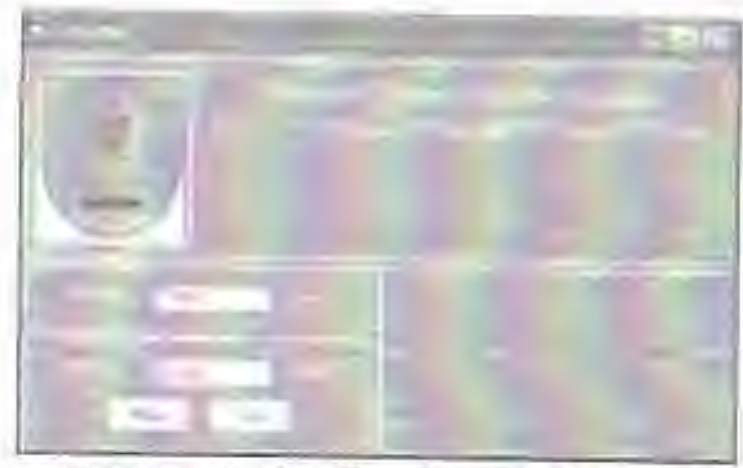

Gambar 21. Tampilan Kendali Detektor

Pada Tampilan kendali detektor ini terdapat 2 frame yaitu frame Devices Status dan frame Devices Control, Frame Devices Status berisi display posisi detektor sebelum dan sesudah detektor, Logfile di atas berarti bahwa posisi detektor berada pada jarak $3000 \mathrm{~mm}$ (millimeter) atau $3 \mathrm{~m}$ (meter). Tombol STOP pada kendali detektor digunakan untuk menghentikan pergerakan detektor. Pada frame Devices Control terdapat kotak Move To. Puda kotak Move To ini disikan jarak detektor yang diinginkan. Tombol Move digunakan untuk meggerakkan detektor, saat tombol Move ditekan maka detektor akan bergerak sesuai dengan jarak yang diisikan pada kotak Move To. Setelah detektor bergerak pada posisi/jarak. yang diinginkan maka motor akan berhenti dan posisi terakhir detektor setelah digerakkan akan disimpan dalam bentuk logfile sebagai berikut: Lastposdel, 300 .

\section{KESIMPULAN}

1. Telah berhasil dikembangkan sistem kendali baru pada fasilitas Small Angle Neutron Scattering (SANS).

2. Telah berhasil dibuat perangkat keras yang menghubungkan antara PMX-4ETSA-TBS motion controller dengan motor driver Vexta 5 phasa. 
3. Telah berhasil dibuat program dengan menggunakan Visual Basic 6 yang dapat menggerakkan motor pada kolimator, detektor, dan pinhole sesuai dengan posisi yang diinginkan.

\section{SARAN}

Dapat ditambahkan form untuk menampilkan selisih pulsa motor stepper pada kendali kolimator saat

\section{DAFTAR PUSTAKA}

1. Sulasno, Thomas Agus Prayitno, "Teknik Sistem Kontrol", Yogyakarta: Graha Ilmu, (2006)

2. Putra, E.G.R, Bharoto, Baek Seok Seong, "Recent Development of a 36 meter Small-Angle Neutron Scattering BATAN Spectrometer (SMARTer) in Serpong Indonesia", Journal of Physics: Conference Series 247, 2010, 012010.

3. http://batan.go.id/ Neutron Scattering Laboratory. Diakses pada 10 Nopember 2012

4. http:/hanafi29.files.wordpress.com

Diakses pada tanggal 10 November 2012.

5. http://installist.files. wordpress.com/2009/ 12/dasar-motor-stepper.pdf Diakses pada tangga

6. Suliswanto, "Tugas Akhir D-IV Program Studi Elektronika Instrumentasi Jurusan Teknofisika Nuklir Rancang Bangun Sistem Monitor Radiasi Nirkabel", Yogyakarta, (2010) 